\title{
Relationship Between HIV Risk Perception And Condom Use: Evidence from a Population-Based Survey in Mozambique
}

\author{
By Ndola Prata, \\ Leo Morris, Elizio \\ Mazive, Farnaz \\ Vahidnia and \\ Mark Stehr
}

Ndola Prata is assistant adjunct professor of maternal and child

health and international health, and

Farnaz Vahidnia is associate specialist in international health,

both at the Bixby Population Program, School of Public

Health, University of California, Berkeley,

CA, USA. Leo Morris is chief, Behavioral Epidemiology and Demographic Research Branch, Division of Reproductive Health, U.S. Centers for Disease Control and Prevention, Atlanta GA, USA. Elizio

Mazive is survey researcher, Department of Statistics,

National Institute of

Statistics, Maputo,

Mozambique. Mark

Stehr is assistant professor of economics,

LeBow College of Business, Drexel University, Philadelphia, PA, USA.

\begin{abstract}
CONTEXT: The relationship between individuals' perception of their risk for acquiring HIV and their use of condoms is poorly understood. Understanding this relationship is crucial to the development of effective strategies to fight HIV and AIDS.
\end{abstract}

METHODS: Data from the Mozambique 2001 Adolescent and Young Adult Reproductive Health and Behavior Risk Survey are used to compare 15-24-year-olds' assessments of their HIV risk with assessments based on current and past sexual behavior. In bivariate and probit regression analyses, the relationship between correct risk assessment and the likelihood of condom use at last intercourse is examined.

RESULTS: Twenty-seven percent of women and $80 \%$ of men who considered themselves to have no risk or a small risk of contracting HIV were actually at moderate or high risk. For both men and women, the prevalence of condom use at last sex was more than twice as high among those who assessed their risk correctly (30\% and 16\%, respectively) as among those who did not (14\% and 6\%). Multivariate analysis showed that correct assessment was positively associated with condom use; the association was driven by use among never-married individuals. Never-married males who assessed their risk correctly were 18\% more likely than other males to report condom use; never-married females, $17 \%$ more likely than other females.

CONCLUSIONS: Educational messages should aim at enabling individuals to correctly assess their own HIV risk and encouraging behavior change based on self-assessment of risk.

International Family Planning Perspectives, 2006, 32(4):192-200

In 2000, an estimated $12 \%$ of adults aged 15-49 in Mozambique were infected with HIV. ${ }^{1}$ Most estimates show an increasing prevalence of infection, and about one-half of new infections occur among 15-24-year-olds. ${ }^{2}$ Nevertheless, according to the 1997 Mozambique Demographic and Health Survey (DHS), young adults had an extremely low rate of condom use. ${ }^{3}$

Individuals' knowledge of HIV transmission and accurate assessment of their own risk seem to be among the key factors in adoption of safer sexual practices. ${ }^{4}$ Policymakers must understand these factors to design effective policies in the fight against HIV and AIDS. Adolescent and young adult behavior is of special interest for several reasons. First, the number of life-years saved is greatest when infections are averted in relatively young individuals. Second, preventing HIV infection in women of childbearing age prevents transmission from mother to child. Finally, it may be easier to change sexual attitudes, practices and risky behaviors among the young than among older people. ${ }^{5}$

In Mozambique, the response to HIV/AIDS has included educational programs, media campaigns, social marketing of condoms, and voluntary counseling and testing services. All of these programs aim to provide individuals with information about HIV transmission, thereby allowing them to make informed choices. The hope has been that acquired knowledge will lead to changes in sexual behav- ior that will help prevent the spread of the disease. However, policymakers and program officials have not had access to adequate population-based data for adolescents and young adults to develop targeted programs and evaluation strategies.

\section{KNOWLEDGE, RISK PERCEPTION AND BEHAVIOR}

According to the AIDS risk reduction model, knowledge of AIDS is a prerequisite to recognizing risky behavior and taking action to change it, ${ }^{6}$ but findings regarding the relationship between knowledge and behavior have been inconsistent. In a review study, Becker and Joseph found an ecological correlation between AIDS knowledge and behavior among bisexual or homosexual men and young heterosexual adults. ${ }^{7}$ However, they did not find clear evidence on the mechanism of this correlation and suggested that a third factor may link knowledge to behavior. In Zambia, Magnani et al. found HIV/AIDS knowledge to be associated with a reduced probability of sexual experience and an elevated probability of condom use among boys. ${ }^{8}$ A cross-sectional study using DHS data from Uganda, Kenya and Zambia showed that knowing somebody with AIDS was predictive of protective sexual behavior, as were knowledge of HIV prevention methods and correct beliefs regarding AIDS patients. ${ }^{9}$ The authors concluded that knowledge of someone who had AIDS or who had died of AIDS may increase an in- 
dividual's awareness of the consequences of HIV/AIDS and may lead to safer sexual practices.

Other studies have reported a lack of association between HIV/AIDS knowledge and sexual behavior. In a survey of almost 1,500 Rwandan women, the vast majority had correct knowledge of HIV transmission, but only a small proportion had adopted any protective behavior in the last year. ${ }^{10} \mathrm{Sex}-$ ually active students in Dar-es-Salaam, Tanzania, who knew that condom use prevents HIV infection had a reduced likelihood of always using condoms. ${ }^{11}$ In Ethiopia, a cohort study of factory workers with a high prevalence of HIV reported high-risk sexual behavior and low condom use, even though the majority mentioned condom use as the best way to prevent HIV. ${ }^{12}$ A study using 1998 Kenyan DHS data reported that the odds of having risky sexual behavior were more than tripled among men and women who perceived their risk of HIV/AIDS as high, and found no association between knowledge of HIV transmission and sexual behavior. ${ }^{13}$

The relationship between perception of risk and sexual behavior is complex and poorly understood. Studies conducted in different cultures have associated HIV risk perception with a wide range of variables: number of sexual partners, knowledge of sexual partners' past sexual behavior, fear of AIDS, shame associated with having AIDS, community perception of AIDS risk, knowing someone with AIDS, discussing AIDS at home, closeness of parent-child relationships and religious affiliation. ${ }^{14}$ In Sub-Saharan Africa, sociocultural norms and practices are major determinants of sexual risk-taking behavior. ${ }^{15}$

A study of South African couples found that women who considered themselves at risk of HIV because of their husbands were four times as likely to use condoms as women who did not. ${ }^{16}$ In a study of university students in Zimbabwe and Nigeria, those who used condoms were more likely than nonusers to have an accurate perception of their HIV risk. ${ }^{17}$ Personal risk perception was also associated with increased condom use among urban youth in Cameroon. ${ }^{18}$ In Ghana, self-perceived high risk among youth was associated with sharply increased odds of condom use at last sex. ${ }^{19}$

The goal of our study is to examine whether correct assessment of HIV risk is associated with condom use at last sex among young adults in Mozambique. We describe youths' attitudes toward HIV and AIDS, and determine whether they have correct information on how the virus is transmitted. We also analyze whether individuals' self-assessment of risk is accurate in light of their sexual behavior.

\section{METHODS}

Our study uses data from the Adolescent and Young Adult Reproductive Health and Behavioral Risk Survey (known by its Portuguese acronym, INJAD), a national, populationbased survey conducted from July to November 2001.* The

*INJAD was conducted by the National Institute of Statistics, in collaboration with the Ministry of Health and the National Office of Youth. The project received technical assistance from the U.S. Centers for Disease Control and Prevention (CDC), and funding from multiple sources, including the U.S. Agency for International Development, UNICEF, the United Nations Population Fund and the CDC Global AIDS Program.

\begin{tabular}{|c|c|c|}
\hline Characteristic & $\begin{array}{l}\text { Males } \\
(\mathrm{N}=3,831)\end{array}$ & $\begin{array}{l}\text { Females } \\
(\mathrm{N}=3,986)\end{array}$ \\
\hline \multicolumn{3}{|l|}{ DEMOGRAPHIC } \\
\hline \multicolumn{3}{|l|}{ Age-group } \\
\hline 15-19 & 44.5 & 42.8 \\
\hline $20-24$ & 55.5 & 57.2 \\
\hline \multicolumn{3}{|l|}{ Residence } \\
\hline Rural & 64.8 & 71.9 \\
\hline Urban & 35.2 & 28.1 \\
\hline \multicolumn{3}{|l|}{ Education } \\
\hline None & 70.6 & 81.6 \\
\hline $1-3$ yrs. & 12.7 & 8.0 \\
\hline 4-6yrs. & 14.3 & 8.2 \\
\hline zsecondary & 2.4 & 2.2 \\
\hline \multicolumn{3}{|l|}{ Marital status } \\
\hline Never-married & 73.4 & 28.8 \\
\hline Ever-married & 27.7 & 71.2 \\
\hline \multicolumn{3}{|c|}{ SEXUAL BEHAVIOR } \\
\hline \multicolumn{3}{|c|}{ Age at first intercourse } \\
\hline$<15$ & 30.9 & 24.2 \\
\hline $15-17$ & 46.5 & 55.5 \\
\hline$\geq 18$ & 22.6 & 20.3 \\
\hline \multicolumn{3}{|c|}{ Cumulative no. of partners } \\
\hline 1 & 16.2 & 55.3 \\
\hline 2 & 13.3 & 22.3 \\
\hline 3 & 13.6 & 10.3 \\
\hline$\geq 4$ & 57.0 & 12.1 \\
\hline \multicolumn{3}{|c|}{ Type of partner at last sex } \\
\hline Husband/wife & 21.6 & 67.5 \\
\hline Regular & 69.4 & 25.9 \\
\hline Occasional & 9.0 & 6.6 \\
\hline \multicolumn{3}{|c|}{ Received money or gifts for sex $†$} \\
\hline Yes & na & 18.8 \\
\hline No & na & 81.2 \\
\hline \multicolumn{3}{|c|}{$\begin{array}{l}\text { Age difference between respondent } \\
\text { and last sexual partner (yrs.)‡ }\end{array}$} \\
\hline 0 & $9.6 \S$ & 5.1 \\
\hline $1-2$ & 30.4 & 14.4 \\
\hline $3-4$ & 25.1 & 18.0 \\
\hline$\geq 5$ & 16.3 & 32.0 \\
\hline Does not know & 18.7 & 30.5 \\
\hline \multicolumn{3}{|c|}{ AIDS-RELATED } \\
\hline \multicolumn{3}{|c|}{ History of STI symptoms } \\
\hline Yes & 17.9 & 21.5 \\
\hline No & 82.1 & 78.5 \\
\hline \multicolumn{3}{|c|}{ Has known someone with AIDS } \\
\hline Yes & 38.0 & 33.6 \\
\hline No & 62.0 & 66.4 \\
\hline \multicolumn{3}{|c|}{ Ever used counseling/testing services } \\
\hline Yes & 3.4 & 1.7 \\
\hline No & 96.6 & 96.3 \\
\hline Total & 100.0 & 100.0 \\
\hline
\end{tabular}

†Asked of never-married women only; refers to last sexual encounter. ‡Refers to how much older than his partner a male respondent was or how much younger than her partner a female respondent was. SIncludes 3.7\% whose partner was older than they were. Note: na=not applicable. 


\begin{tabular}{|c|c|c|c|c|}
\hline \multirow[t]{2}{*}{ Imputed } & \multicolumn{4}{|c|}{ Self-assessed } \\
\hline & Total & None/small & Moderate/high & $\begin{array}{l}\text { Does not } \\
\text { know }\end{array}$ \\
\hline Females & $(\mathrm{N}=3,986)$ & $(\mathrm{N}=1,505)$ & $(\mathrm{N}=1,048)$ & $(\mathrm{N}=1,433)$ \\
\hline None/small & 58.9 & 73.3 & 0.0 & 76.8 \\
\hline Moderate/high & 41.1 & 26.7 & 100.0 & 23.3 \\
\hline Males & $(\mathrm{N}=3,831)$ & $(\mathrm{N}=1,638)$ & $(\mathrm{N}=1,643)$ & $(\mathrm{N}=550)$ \\
\hline None/small & 8.9 & 20.1 & 0.0 & 7.9 \\
\hline Moderate/high & 91.1 & 79.9 & 100.0 & 92.1 \\
\hline Total & 1000 & 1000 & 1000 & 1000 \\
\hline
\end{tabular}

survey included questions about school attendance and sex education, knowledge of contraception, sexual experience and current sexual activity, opinions about condoms, sexuality and gender issues, prenatal care and maternal morbidity, HIV/AIDS, and physical and sexual abuse.

Details about the INJAD methodology can be found in the survey report. ${ }^{20}$ The survey followed a two-stage probability household sample design, using the master sample from the 1997 census as a sampling frame. Complete interviews were conducted with 5,338 females aged 15-24 (for an 88\% response rate) and 5,150 males in the same age-group ( $81 \%$ response rate). Our analyses are based on sexually experienced respondents-3,831 males and 3,986 females. The female and male samples were independent of each other. Differences between sample estimates were calculated using an average design effect of 1.5.

Respondents assessed their risk of HIV infection as none, small, moderate, high or not known. To evaluate the accuracy of perceived risk, we compared these self-assessments with assessments imputed on the basis of current and past sexual behavior. For the imputed assessment, we summed the number of risk factors respondents reported from among the following: having not used a condom at last sex, having had an occasional partner at last sex, having had three or more partners in the last 12 months, having had six or more cumulative partners, having a history of STIs and, for never-married women, having received money or gifts in exchange for the most recent sexual encounter. Respondents reporting fewer than two risk factors were defined as having no risk or a low risk of HIV infection; those reporting two or more were defined as having a moderate or high risk of HIV.

We used chi-square and t tests to compare the proportions of respondents, within and across subgroups, who correctly assessed their HIV risk and the proportions who reported condom use at last sex. To test the association between condom use and correct assessment of HIV risk, controlling for demographic, behavioral and HIV-related variables of interest, we used a probit regression model with condom use at last sex as the outcome variable. To run the model, we removed condom use from the risk definition variable, and removed all of the variables included in the imputed risk definition from the righthand side of the equation. In this way, each variable appears only once, in one side of the equation, and the problem of endogeneity is avoided.

Data analysis was performed with Stata 6. Coefficients shown are equal to the change in the probability of condom use associated with a change of one unit in the independent variable. All results are given separately for females and males; within each gender, results are disaggregated by marital status. Marital status was coded as ever-married or never-married; the ever-married category includes respondents who were married, cohabiting, separated, divorced, widowed, or legally married but not living in the same house as their spouse.

\section{RESULTS}

\section{Sample Characteristics}

Slightly more than half of both sexually experienced males and their female counterparts were 20-24 years old, and about seven in 10 of each came from rural areas (Table 1 , page 193). The vast majority of respondents had no formal schooling. Twenty-eight percent of men and $71 \%$ of women had ever married.

To explore respondents' reproductive lives, we used questions that asked them to recall the first time a life event occurred. For women, the median age at menarche was 14.0 years, the median age at first sex was 15.9, and the median age at first pregnancy and at first marriage was 19.0 (not shown). For men, the median age at first sex was 15.6 years, the median age at the birth of the first child was 23 and the median age at first marriage was 24 .

Fifty-seven percent of sexually experienced males had had four or more partners; $12 \%$ of women reported this cumulative number of partners (Table 1). Similarly, 53\% of men and $9 \%$ of women had had two or more partners in the last 12 months (not shown). Nine percent and 7\%, respectively, had last had sex with an occasional partner. Among never-married women, 19\% reported receiving money or goods in exchange for sex at the time of the last sexual encounter. Among the men, one in five did not know their last partner's age, and three in 10 said that she was 1-2 years younger. Almost a third of the women did not know the age of their last partner; another third said that he had been five or more years their senior.

Some $18 \%$ of men and $22 \%$ of women reported a history of symptoms or signs associated with an STI. Thirtyeight percent of men and 34\% of women had known someone who was HIV-positive or who died of AIDS. However, the use of voluntary counseling and testing services was very low; fewer than $5 \%$ of either men or women had obtained services. About three-fourths of respondents said that they would care for a family member who was HIVpositive, but $55 \%$ of women and $47 \%$ of men would keep it a secret if a relative had AIDS (not shown).

When asked how HIV is transmitted, only $8 \%$ of men and 3\% of women gave answers that were incorrect (e.g., by kissing or holding hands, or through witchcraft or mosquito bites); $98 \%$ of men and $91 \%$ of women spontaneously mentioned at least one documented cause of transmission (not shown). However, only $79 \%$ of men and $74 \%$ of women 
knew that a person could look healthy and be infected with HIV. These findings are consistent with previous survey reports that people may know some specific modes of transmission, but lack a general understanding of the disease. ${ }^{21}$

\section{HIV Risk Assessment}

Overall, 32\% of women considered themselves at no or low risk of contracting HIV, 22\% thought they were at moderate or high risk, and $46 \%$ did not know how to assess their HIV risk. According to our imputed estimates, 27\% of women who considered themselves at no or low risk, and $23 \%$ who reported not knowing how to assess their risk, were at moderate or high risk of HIV infection (Table 2). The situation for men is even more troubling. Thirty-eight percent said that they had no or low risk of acquiring HIV, 46\% that they had a moderate or high risk, and $17 \%$ that they did not know (not shown). However, $80 \%$ of those who considered themselves at no or low risk, and $92 \%$ of those who did not know how to assess their risk, were classified as having a moderate or high risk of HIV infection.

According to our risk reassessment, $53 \%$ of men and $46 \%$ of women had an accurate perception of their risk (Table 3). The proportions were $45 \%$ and $43 \%$, respectively, among ever-married men and women, and 56\% and 50\% among their never-married counterparts; the differences by marital status were statistically significant (not shown). Furthermore, within each subgroup of marital status, correct assessment of risk differed according to an individual's characteristics. For example, correct assessment of risk increased with level of education among women, particularly among never-married women, whereas it showed no clear pattern in relation to education among men. Correct assessment also increased with number of lifetime partners for women, regardless of marital status, but showed no clear pattern for men.

Among never-married respondents, the likelihood of correct risk assessment rose significantly with age at first intercourse among women but was not associated with this characteristic among men. However, among ever-married respondents, it was inversely associated with men's age at first sex and not associated with women's. Overall, the proportion of respondents who correctly assessed their risk was significantly higher among those who reported condom use at last sex ( $70 \%$ of men and $71 \%$ of women) than among those who did not ( $48 \%$ and $42 \%$, respectively). Furthermore, the differences in levels of correct assessment between never-married men and women who had used a condom at last sex ( $72 \%$ and $76 \%$, respectively) and their ever-married counterparts (61\% and 58\%, respectively) were statistically significant (not shown).

Partner type was related to correct assessment except for ever-married females and never-married males; nevermarried women who had last had sex with an occasional partner were less likely than those reporting a regular partner to assess their risk correctly (24\% vs. $56 \%$ ). Across all subgroups, those with a history of STI symptoms were more likely than others to assess themselves correctly. For women TABLE 3. Percentage of sexually experienced respondents who correctly assessed
their risk of HIV, by selected characteristics, according to marital status and gender

Characteristic

\begin{tabular}{ll|ll|ll}
\multicolumn{2}{l|}{} & \multicolumn{2}{|c|}{ Ever-married } & \multicolumn{2}{l}{ Never-married } \\
\hline $\begin{array}{l}\text { Males } \\
(\mathrm{N}=3,831)\end{array}$ & $\begin{array}{l}\text { Females } \\
(\mathrm{N}=3,986)\end{array}$ & $\begin{array}{l}\text { Males } \\
(\mathrm{N}=738)\end{array}$ & $\begin{array}{l}\text { Females } \\
(\mathrm{N}=2,464)\end{array}$ & $\begin{array}{l}\text { Males } \\
(\mathrm{N}=3,093)\end{array}$ & $\begin{array}{l}\text { Females } \\
(\mathrm{N}=1,522)\end{array}$ \\
$\mathbf{5 3 . 1}$ & $\mathbf{4 5 . 5}$ & $\mathbf{4 5 . 2}$ & $\mathbf{4 3 . 4}$ & $\mathbf{5 6 . 2}$ & $\mathbf{5 0 . 2}$
\end{tabular}

\begin{tabular}{|c|c|c|c|c|c|c|}
\hline Total & 53.1 & 45.5 & 45.2 & 43.4 & 56.2 & 50.2 \\
\hline \multicolumn{7}{|l|}{ DEMOGRAPHIC } \\
\hline $15-19$ & 52.1 & 45.7 & 41.5 & 42.3 & 52.7 & 49.4 \\
\hline $20-24$ & 53.9 & 45.3 & $45.6^{* *}$ & 44.0 & $60.9^{* * *}$ & 52.0 \\
\hline \multicolumn{7}{|l|}{ Residence } \\
\hline Rural & 51.3 & 42.3 & 44.8 & 42.9 & 54.9 & 40.5 \\
\hline Urban & $56.3^{* * *}$ & $52.8^{* * *}$ & $47.0^{* *}$ & 45.2 & $58.0^{* *}$ & $61.2^{* * *}$ \\
\hline \multicolumn{7}{|l|}{ Education } \\
\hline None & 59.9 & 38.3 & 47.9 & 40.4 & 66.7 & 28.0 \\
\hline $1-3$ yrs. & 50.9 & 44.8 & 44.0 & 44.8 & 54.4 & 45.0 \\
\hline 4-6yrs. & 50.2 & 52.6 & 49.1 & 45.9 & 50.5 & 59.3 \\
\hline$\geq$ secondary & $58.0^{* * *}$ & $69.2^{* * *}$ & $38.6^{* * *}$ & $56.0^{* * *}$ & 60.7 & $72.9^{* * *}$ \\
\hline \multicolumn{7}{|c|}{ SEXUAL BEHAVIOR } \\
\hline \multicolumn{7}{|c|}{ Age at first intercourse } \\
\hline$<15$ & 58.7 & 51.5 & 60.2 & 51.7 & 58.3 & 51.2 \\
\hline $15-17$ & 50.7 & 48.9 & 43.9 & 48.0 & 52.6 & 50.8 \\
\hline$\geq 18$ & $51.0^{*}$ & 47.6 & $38.2^{* *}$ & 44.1 & 60.2 & $58.9^{*}$ \\
\hline \multicolumn{7}{|c|}{ Cumulative no. of partners } \\
\hline 1 & 41.1 & 43.4 & 30.5 & 42.8 & 45.2 & 45.0 \\
\hline 2 & 56.7 & 45.1 & 41.5 & 43.1 & 62.1 & 48.6 \\
\hline 3 & 46.1 & 48.0 & 34.3 & 42.9 & 49.4 & 54.7 \\
\hline$\geq 4$ & 57.3 & $56.9^{* * *}$ & 53.0 & $54.6^{* * *}$ & 59.1 & $61.6^{* * *}$ \\
\hline \multicolumn{7}{|c|}{ Condom use at last sex } \\
\hline Yes & 70.0 & 71.0 & 60.7 & 57.7 & 71.6 & 75.5 \\
\hline No & $47.5^{* * *}$ & $42.2^{* * *}$ & $43.1^{* * *}$ & $42.4^{* *}$ & $49.6^{* * *}$ & $41.7^{* * *}$ \\
\hline \multicolumn{7}{|c|}{ Type of partner at last sex } \\
\hline Husband/wife & 40.4 & 43.2 & 40.1 & 43.2 & na & na \\
\hline Regular & 56.1 & 55.0 & 63.2 & 41.7 & 56.5 & 56.3 \\
\hline Occasional & $54.2^{* * *}$ & $26.4^{* * *}$ & $54.8^{* *}$ & 36.2 & 55.5 & $23.7^{* * *}$ \\
\hline \multicolumn{7}{|c|}{ Received money or gifts for sex $†$} \\
\hline Yes & na & na & na & na & na & 37.7 \\
\hline No & na & na & na & na & na & $53.7^{* * *}$ \\
\hline \multicolumn{7}{|c|}{$\begin{array}{l}\text { Age difference between respondent } \\
\text { and last sexual partner (yrs.)‡ }\end{array}$} \\
\hline 0 & 51.5 & 49.0 & 40.6 & 45.1 & 54.8 & 53.5 \\
\hline $1-2$ & 48.4 & 53.0 & 40.7 & 48.4 & 50.9 & 58.1 \\
\hline $3-4$ & 48.7 & 54.6 & 35.1 & 51.6 & 55.5 & 60.9 \\
\hline$\geq 5$ & 56.3 & 45.9 & 57.0 & 43.3 & 55.8 & 63.0 \\
\hline Does not know & $59.7^{*}$ & $35.1^{* * *}$ & 53.6 & $35.6^{* * *}$ & 61.3 & $34.1^{* * *}$ \\
\hline \multicolumn{7}{|c|}{ AIDS-RELATED } \\
\hline \multicolumn{7}{|c|}{ History of STI symptoms } \\
\hline Yes & 58.4 & 48.7 & 54.8 & 47.3 & 59.9 & 52.3 \\
\hline No & $52.0^{* * *}$ & $34.6^{* * *}$ & $42.9^{* *}$ & $29.9 * * *$ & $55.4^{* *}$ & $43.5^{* * *}$ \\
\hline \multicolumn{7}{|c|}{ Has known someone with AIDS } \\
\hline Yes & 52.9 & 55.5 & 47.1 & 52.2 & 56.7 & 61.3 \\
\hline No & 53.3 & $40.3^{* * *}$ & $41.5^{*}$ & $39.5^{* * *}$ & 5.9 & $42.5^{* * *}$ \\
\hline \multicolumn{7}{|c|}{ Ever used counseling/testing services } \\
\hline Yes & 55.9 & 71.7 & 49.7 & 75.5 & 58.5 & 69.7 \\
\hline No & 53.0 & $45.0^{* *}$ & $45.0^{*}$ & $43.1^{*}$ & 56.1 & $49.6^{*}$ \\
\hline
\end{tabular}

${ }^{*} \mathrm{p}<.05 .{ }^{* *} \mathrm{p}<.01 .{ }^{* * * *} \mathrm{p}<.001$. $\dagger$ Asked of never-married women only; refers to last sexual encounter. $¥$ Refers to how much older than his partner a male respondent was or how much younger than her partner a female respondent was. Note: na=not applicable.

in both marital status groups and for ever-married men, the likelihood of correct assessment was elevated among those who had known someone with AIDS. Although the use of counseling and testing services is extremely rare in 
TABLE 4. Percentage of sexually experienced respondents who reported condom use at last sex, by selected characteristics, according to marital status and gender

\begin{tabular}{|c|c|c|c|c|c|c|}
\hline \multirow[t]{2}{*}{ Characteristic } & \multicolumn{2}{|l|}{ Total } & \multicolumn{2}{|c|}{ Ever-married } & \multicolumn{2}{|c|}{ Never-married } \\
\hline & Males & Females & Males & Females & Males & Females \\
\hline Total & 21.7 & 9.5 & 11.2 & 3.4 & 25.8 & 24.9 \\
\hline \multicolumn{7}{|l|}{ DEMOGRAPHIC } \\
\hline $15-19$ & 20.9 & 14.5 & 12.3 & 4.8 & 21.4 & 25.9 \\
\hline $20-24$ & 22.4 & $5.7^{* * *}$ & 11.1 & $2.7^{*}$ & $31.9^{* * *}$ & 21.7 \\
\hline \multicolumn{7}{|l|}{ Residence } \\
\hline Rural & 13.8 & 4.4 & 8.2 & 2.1 & 16.7 & 12.9 \\
\hline Urban & $36.5^{* * *}$ & $22.1^{* * *}$ & $23.7^{* * *}$ & $8.1^{* * *}$ & $38.8^{* * *}$ & $38.0^{* * *}$ \\
\hline \multicolumn{7}{|l|}{ Education } \\
\hline None & 8.1 & 1.1 & 4.3 & 1.0 & 10.1 & 2.7 \\
\hline $1-3$ yrs. & 14.7 & 7.4 & 9.8 & 4.5 & 17.2 & 15.6 \\
\hline 4-6yrs. & 25.5 & 24.5 & 17.9 & 8.0 & 27.7 & 40.5 \\
\hline$\geq$ secondary & $48.8^{* * *}$ & $41.9^{* * *}$ & $22.6^{* * *}$ & $16.5^{* * *}$ & $52.5^{* * *}$ & $49.1^{* * *}$ \\
\hline \multirow{2}{*}{\multicolumn{7}{|c|}{$\begin{array}{l}\text { SEXUAL BEHAVIOR } \\
\text { Age at first intercourse }\end{array}$}} \\
\hline & 20.6 & 12.6 & 16.1 & 4.8 & 22.0 & 24.5 \\
\hline $15-17$ & 24.9 & 11.7 & 14.3 & 4.3 & 27.9 & 27.2 \\
\hline$\geq 18$ & 22.6 & 7.2 & 7.4 & 2.6 & 33.5 & 23.2 \\
\hline \multicolumn{7}{|c|}{ Cumulative no. of partners } \\
\hline 1 & 12.1 & 7.1 & 3.1 & 2.8 & 15.9 & 21.5 \\
\hline 2 & 21.7 & 11.3 & 5.7 & 3.7 & 27.4 & 24.8 \\
\hline 3 & 25.8 & 13.4 & 9.1 & 5.1 & 30.3 & 24.9 \\
\hline$\geq 4$ & 23.0 & 11.0 & $14.9^{*}$ & 4.3 & $26.3^{* *}$ & 25.1 \\
\hline \multicolumn{7}{|c|}{ Type of partner at last sex } \\
\hline Husband/wife & 7.1 & 2.8 & 7.1 & 2.8 & na & na \\
\hline Regular & 26.0 & 26.1 & 25.1 & 14.3 & 26.1 & 27.2 \\
\hline Occasional & $24.0^{* * *}$ & 13.2 & $24.4^{* * *}$ & 14.4 & 23.9 & 12.9 \\
\hline \multicolumn{7}{|c|}{ Received money or gifts for sex $\dagger$} \\
\hline Yes & na & na & na & na & na & 27.8 \\
\hline No & na & na & na & na & na & 24.3 \\
\hline \multicolumn{7}{|c|}{$\begin{array}{l}\text { Age difference between respondent } \\
\text { and last sexual partner (yrs.)‡ }\end{array}$} \\
\hline 0 & 29.5 & 18.7 & 6.8 & 4.4 & 36.6 & 38.9 \\
\hline $1-2$ & 24.5 & 22.6 & 11.0 & 6.8 & 28.7 & 38.8 \\
\hline $3-4$ & 25.2 & 14.2 & 11.8 & 4.9 & 31.9 & 34.3 \\
\hline$\geq 5$ & 21.1 & 7.2 & 14.6 & 3.7 & 24.9 & 32.4 \\
\hline Does not know & $11.1^{* * *}$ & $2.5^{* * *}$ & $5.9^{* * *}$ & $0.8^{*}$ & 32.0 & $5.2^{* *}$ \\
\hline \multicolumn{7}{|c|}{ AIDS-RELATED } \\
\hline \multicolumn{7}{|c|}{ History of STI symptoms } \\
\hline Yes & 24.7 & 16.5 & 23.8 & 6.8 & 25.1 & 20.9 \\
\hline No & $21.1^{*}$ & $7.5^{* * *}$ & $8.2^{* *}$ & $2.5^{* * *}$ & 26.0 & $35.6^{* * *}$ \\
\hline \multicolumn{7}{|c|}{ Has known someone with AIDS } \\
\hline Yes & 29.9 & 17.6 & 17.0 & 7.1 & 34.3 & 35.7 \\
\hline No & $17.3^{* * *}$ & $6.7^{* * *}$ & $8.3^{* *}$ & $2.3^{* * *}$ & $21.2^{* * *}$ & $18.2^{* * *}$ \\
\hline \multicolumn{7}{|c|}{ Ever used counseling/testing services } \\
\hline Yes & 47.6 & 39.4 & 26.1 & 13.0 & 56.6 & 52.9 \\
\hline No & $21.2^{* * *}$ & $6.8^{* * *}$ & $10.7^{* *}$ & $3.7^{* * *}$ & $25.3^{* * *}$ & $24.2^{* * *}$ \\
\hline \multicolumn{7}{|c|}{ Assessment of HIV risk } \\
\hline Correct & 29.5 & 16.2 & 15.2 & 5.0 & 34.0 & 38.0 \\
\hline Incorrect & $13.9^{* * *}$ & $5.5^{* * *}$ & $8.0^{* * *}$ & $2.8^{* *}$ & $16.8^{* * *}$ & $12.4^{* * *}$ \\
\hline
\end{tabular}

${ }^{*} p<05 .{ }^{* *} p<.01 .{ }^{* * *} p<.001$. †Asked of never-married women only; refers to last sexual encounter. \#Refers to how much older than his partner a male respondent was or how much younger than her partner a female respondent was. Note: na=not applicable.

Mozambique, females who had used these services appeared to be more likely than others to make a correct assessment of risk ( $72 \%$ vs. $45 \%)$; this relationship holds both for those who had ever married ( $76 \%$ vs. $43 \%$ ) and for those who had not ( $70 \%$ vs. $50 \%$ ). Additionally, a greater proportion of females than of males who had used counseling services made a correct assessment of their risk.

\section{Condom Use at Last Sex}

According to INJAD, the prevalence of condom use was low overall in 2001: Twenty-two percent of men and 10\% of women reported use at last sex (Table 4), and the difference was statistically significant (not shown). Prevalence among never-married women was much higher than average (25\%) and was similar to the level among nevermarried men (26\%). The likelihood of condom use was positively related to age only among never-married men; in all subgroups, it was higher in urban areas than in rural areas, and it increased with level of education. Condom use was low among ever-married individuals, but was significantly more common among those whose last partner had been someone other than a spouse. Among ever-married males (but not their female counterparts), condom use was significantly more common with regular or occasional partners than with spouses. Respondents who did not know their last partner's age-particularly females, regardless of their marital status-were less likely than others to have used condoms at last sex. Having a history of STI symptoms was related to an increased likelihood of condom use at last sex for all subgroups except never-married men, and having known someone with AIDS and having used counseling and testing services were positively associated with condom use for every subgroup. Finally, condom use was more than twice as common among respondents who assessed their risk correctly as among those who did not (for males, $30 \%$ vs. $14 \%$; for females, $16 \%$ vs. $6 \%$ ).

According to our probit regression model, sexually experienced men overall were 15\% more likely to use condoms if they correctly assessed their risk of HIV infection than if they did not (Table 5). The differential was more than twice as high among never-married men as among evermarried men (18\% vs. $7 \%$ ). Males who had used counseling and testing services were $16 \%$ more likely to use condoms than were those who had not. This difference was significant only for never-married men. Having known someone with AIDS was associated with a significantly increased likelihood of condom use by males, regardless of their marital status. Findings for the demographic characteristics in the probit regression model were consistent with the bivariate results.

Among women overall, correct assessment of risk was associated with a $5 \%$ increase in the likelihood of condom use (Table 6, page 198); the association was significant only for never-married women, for whom the differential was considerable (17\%). Similarly, the use of counseling and testing services was associated with a significantly higher likelihood of condom use, but only among never-married women (19\%). Having known someone with AIDS was associated with increased condom use among women, regardless of their marital status. Findings for the demographic variables in the model were consistent with the results obtained in the bivariate analysis. 


\section{DISCUSSION}

Studies of the influence of AIDS knowledge on condom use have reported mixed results. Some have found positive associations, ${ }^{22}$ and others no association after various social and demographic characteristics were controlled for. ${ }^{23}$ However, these studies have involved different population subgroups at different risk levels (e.g., gold miners and commercial sex workers). In addition, they have used an array of questions to measure knowledge of AIDS, from general knowledge about HIV transmission and accuracy of responses given about AIDS, to a general understanding of the disease (e.g., how one can became infected or how one can avoid contracting HIV). Our study, which uses a national population-based household sample, representative of all Mozambican youth aged 15-24, contributes to the literature on condom use predictors by looking at the accuracy of individuals' assessment of their own risk, based on current and past sexual behavior.

We found a tendency for young adults, especially young men, to underestimate their risk of contracting HIV: Some $27 \%$ of women and $80 \%$ of men who considered themselves at low or no risk were actually at moderate or high risk of HIV infection. Furthermore, even though men and women overall had accurate knowledge of HIV transmission modes, $17 \%$ and $46 \%$, respectively, did not know how to assess their risk. Two possible reasons for this discrepancy are that women may not apply their knowledge of disease transmission to assess their risk level every time they engage in sexual activity and that women were more reluctant than men to report their self-assessment of risk.

Existing literature has shown mixed results on the association between risk perception and sexual behavior. Our findings suggest that condom use at last sex in this sample was related to a number of factors operating at the individual and environmental levels. It was associated with most of the demographic and behavioral variables included in the analysis. Previous studies have shown positive associations between education and condom use; ${ }^{24}$ ours shows a similar trend, except for women with a secondary or higher education.

Our AIDS-related variables-having known someone with AIDS, having used voluntary counseling and testing services, and correctly assessing one's own risk-were also positively associated with condom use. However, results differ between men and women, and by marital status. Condom use at last sex appears to be more strongly related to correct assessment of risk among never-married than among ever-married men and women, and more among males than among females.

Similarly, the use of counseling and testing services was associated with condom use, but only among nevermarried men and women. Because respondents who had access to and chose to use services are a highly self-selected subsample, these results should be interpreted cautiously. Factors associated with choosing to obtain services may be the cause of the difference. ${ }^{25}$ A study by Sweat et al. ${ }^{26}$ found that individuals obtaining voluntary counseling and
TABLE 5. Coefficients from probit regression analysis of association between males' characteristics and the probability of reporting condom use at last sex

\begin{tabular}{|c|c|c|c|c|c|c|}
\hline \multirow[t]{2}{*}{ Characteristic } & \multicolumn{2}{|l|}{ Total } & \multicolumn{2}{|c|}{ Ever-married } & \multicolumn{2}{|c|}{ Never-married } \\
\hline & Coeff. & S.E. & Coeff. & S.E. & Coeff. & S.E. \\
\hline \multicolumn{7}{|l|}{ DEMOGRAPHIC } \\
\hline \multicolumn{7}{|l|}{ Age-group } \\
\hline $15-19$ & ref & & ref & & ref & \\
\hline $20-24$ & $0.07^{* * *}$ & 0.02 & 0.02 & 0.03 & $0.07^{* * *}$ & 0.02 \\
\hline \multicolumn{7}{|l|}{ Residence } \\
\hline Rural & ref & & ref & & ref & \\
\hline Urban & $0.15^{* * *}$ & 0.02 & $0.12^{* * *}$ & 0.04 & $0.15^{* * *}$ & 0.02 \\
\hline \multicolumn{7}{|l|}{ Education } \\
\hline None & ref & & ref & & ref & \\
\hline $1-3$ yrs. & $0.08^{* * *}$ & 0.02 & 0.07 & 0.05 & $0.08^{* *}$ & 0.03 \\
\hline $4-6 y r s$ & $0.10^{* * *}$ & 0.02 & 0.05 & 0.05 & $0.12^{* * *}$ & 0.03 \\
\hline$\geq$ secondary & $0.12^{* *}$ & 0.52 & -0.03 & 0.93 & $0.14^{* *}$ & 0.06 \\
\hline \multicolumn{7}{|l|}{ Marital status } \\
\hline Never-married & ref & & na & & na & \\
\hline Ever-married & $-0.12^{* * *}$ & 0.02 & na & & na & \\
\hline \multicolumn{7}{|l|}{ SEXUAL BEHAVIOR } \\
\hline \multicolumn{7}{|c|}{ Age at first intercourse } \\
\hline$<15$ & ref & & ref & & ref & \\
\hline $15-17$ & $0.06^{* *}$ & 0.02 & 0.01 & 0.03 & $0.08^{* * *}$ & 0.02 \\
\hline$\geq 18$ & 0.34 & 0.22 & $-0.06^{*}$ & 0.03 & $0.01^{* * *}$ & 0.03 \\
\hline \multicolumn{7}{|c|}{ No. of yrs. older than last sexual partner } \\
\hline 0 & ref & & ref & & ref & \\
\hline $1-2$ & 0.07 & 0.05 & 0.01 & 0.08 & 0.04 & 0.06 \\
\hline $3-4$ & 0.05 & 0.04 & $0.21 * *$ & 0.10 & -0.02 & 0.04 \\
\hline$\geq 5$ & 0.05 & 0.04 & 0.09 & 0.06 & 0.00 & 0.05 \\
\hline Younger than partner & 0.01 & 0.04 & 0.09 & 0.06 & -0.07 & 0.04 \\
\hline Does not know & -0.05 & 0.03 & $0.21^{*}$ & 0.12 & $-0.13^{* *}$ & 0.04 \\
\hline \multicolumn{7}{|l|}{ AIDS-RELATED } \\
\hline \multicolumn{7}{|c|}{ Has known someone with AIDS } \\
\hline No & ref & & ref & & ref & \\
\hline Yes & $0.07^{* * *}$ & 0.15 & $0.07^{* *}$ & 0.03 & $0.07^{* * *}$ & 0.02 \\
\hline \multicolumn{7}{|c|}{ Ever used counseling/testing services } \\
\hline No & ref & & ref & & ref & \\
\hline Yes & $0.16^{* * *}$ & 0.05 & 0.11 & 0.08 & $0.17^{* * *}$ & 0.05 \\
\hline \multicolumn{7}{|c|}{ Assessment of HIV risk† } \\
\hline Incorrect & ref & & ref & & ref & \\
\hline Correct & $0.15^{* * *}$ & 0.01 & $0.07^{* *}$ & 0.02 & $0.18^{* * *}$ & 0.02 \\
\hline Log likelihood & $-1,66$ & & & & $-1,47$ & \\
\hline
\end{tabular}

${ }^{*} \mathrm{p}<.05 .{ }^{* *} \mathrm{p}<.01 .{ }^{* * *} \mathrm{p}<.001 .+$ Based on a measure that excludes condom use, to avoid endogeneity bias. Notes: ref=reference group. S.E.=standard error. na=not applicable. Coefficients are equal to the change in the probability of condom use associated with a one-unit change in the independent variable.

testing services in Tanzania and Trinidad were 3-4 times as likely as those in comparison household probability samples to report unprotected sex with nonprimary and commercial partners; following voluntary testing and counseling, condom use increased by $66 \%$. Because of low access to and availability of voluntary counseling and testing services in Mozambique, participation in counseling and testing is unlikely to be associated with an increase in condom use of the same magnitude reported by Sweat et al. in Tanzania and Trinidad. Studies in Sub-Saharan Africa have shown that as many as $90 \%$ of individuals of reproductive age would use voluntary counseling and testing services if they were available. ${ }^{27}$ It is plausible that Mozambican youth who 


\begin{tabular}{|c|c|c|c|c|c|c|}
\hline \multirow[t]{2}{*}{ Characteristic } & \multicolumn{2}{|l|}{ Total } & \multicolumn{2}{|c|}{ Ever-married } & \multicolumn{2}{|c|}{ Never-married } \\
\hline & Coeff. & S.E. & Coeff. & S.E. & Coeff. & S.E. \\
\hline \multicolumn{7}{|l|}{ DEMOGRAPHIC } \\
\hline $15-19$ & ref & & ref & & ref & \\
\hline $20-24$ & $-0.03^{* *}$ & 0.01 & $-0.02^{*}$ & 0.01 & $-0.07^{*}$ & 0.03 \\
\hline \multicolumn{7}{|l|}{ Residence } \\
\hline Urban & $0.07^{* * *}$ & 0.01 & $0.05^{* * *}$ & 0.01 & $0.12^{* * *}$ & 0.03 \\
\hline \multicolumn{7}{|l|}{ Education } \\
\hline None & ref & & ref & & ref & \\
\hline $1-3$ yrs. & $0.06^{* *}$ & 0.02 & 0.03 & 0.02 & $0.12^{* *}$ & 0.05 \\
\hline 4-6yrs. & $0.04^{* *}$ & 0.02 & -0.0 & 0.01 & $0.10^{* *}$ & 0.04 \\
\hline$\geq$ secondary & 0.03 & 0.03 & 0.01 & 0.03 & 0.07 & 0.06 \\
\hline \multicolumn{7}{|l|}{ Marital status } \\
\hline Never-married & ref & & na & & na & \\
\hline Ever-married & $-0.13^{* * *}$ & 0.01 & na & & na & \\
\hline \multirow{2}{*}{\multicolumn{7}{|c|}{$\begin{array}{l}\text { SEXUAL BEHAVIOR } \\
\text { Age at first intercourse }\end{array}$}} \\
\hline & & & & & & \\
\hline$<15$ & ref & & ref & & ref & \\
\hline $15-17$ & -0.0 & 0.00 & -0.0 & 0.01 & -0.01 & 0.03 \\
\hline$\geq 18$ & -0.01 & 0.01 & -0.01 & 0.01 & -0.03 & 0.04 \\
\hline \multicolumn{7}{|c|}{ No. of yrs. younger than last sexual partner } \\
\hline 0 & ref & & ref & & ref & \\
\hline $1-2$ & -0.01 & 0.02 & -0.01 & 0.02 & -0.04 & 0.04 \\
\hline $3-4$ & -0.03 & 0.01 & -0.01 & 0.02 & -0.08 & 0.04 \\
\hline$\geq 5$ & $-0.04^{*}$ & 0.02 & -0.02 & 0.02 & $-0.10^{*}$ & 0.04 \\
\hline Does not know & $-0.09^{* * *}$ & 0.01 & $-0.04^{*}$ & 0.01 & $-0.26 * *$ & 0.03 \\
\hline \multirow{2}{*}{\multicolumn{7}{|c|}{$\begin{array}{l}\text { AIDS-RELATED } \\
\text { Hasknown sith AIDS }\end{array}$}} \\
\hline & & \multicolumn{5}{|c|}{ Has known someone with AIDS } \\
\hline No & ref & & ref & & ref & \\
\hline Yes & $0.04^{* * *}$ & 0.01 & $0.03^{* *}$ & 0.01 & $0.09^{* * *}$ & 0.02 \\
\hline \multicolumn{7}{|c|}{ Ever used counseling/testing services } \\
\hline No & ref & & ref & & ref & \\
\hline Yes & $0.09^{* *}$ & 0.03 & 0.03 & 0.04 & $0.19^{* *}$ & 0.07 \\
\hline \multicolumn{7}{|c|}{ Assessment of HIV risk† } \\
\hline Correct & $0.05^{* * *}$ & 0.01 & 0.01 & 0.01 & $0.17^{* * *}$ & 0.02 \\
\hline Log likelihood & -92 & & -33 & & & \\
\hline
\end{tabular}

${ }^{*} \mathrm{p}<.05 .{ }^{* *} \mathrm{p}<.01 .{ }^{* * *} \mathrm{p}<.001$. + Based on a measure that excludes condom use, to avoid endogeneity bias. Notes: ref=reference group. S.E.=standard error. na=not applicable. Coefficients are equal to the change in the probability of condom use associated with a one-unit change in the independent variable.

chose to obtain services were more likely than others to change their behavior. On the other hand, those who used services may have done so because they were in relatively high-risk situations, and they may have had little control over behavior such as condom use.

The levels of condom use at last sex reported in our study (22\% among men and 10\% among women) represent significant increases over the levels found in the 1997 DHS ( $7 \%$ and $2 \%$, respectively ${ }^{28}$ ). The finding that use remains lower among ever-married than among never-married individuals is consistent with findings from previous work. ${ }^{29}$ With HIV prevalence high in Mozambique, it is important to encourage condom use in all types of sexual relationships, including consensual and legal unions, since both married and unmarried individuals engage in risky sexu- al behaviors (e.g., multiple partners and unprotected sex with nonregular partners). Furthermore, condom use may signal mistrust. ${ }^{30}$ Addressing these issues in information and education campaigns, including encouraging testing for married and regular partners and continued use of condoms until the couple is able to undergo counseling and testing, should be an important component of HIV prevention efforts.

\section{Conclusions}

The AIDS epidemic is complex, and successful efforts to limit transmission must rely on a combination of medical, social and behavioral approaches. It is clear that young people should be at the center of strategies to control HIV infection. The population-based data from this survey provide information that will enable program officials and policymakers to design more effective HIV prevention programs for Mozambican youth. Adolescents' and young adults' reproductive health knowledge and their sexual and contraceptive behavior can have important implications for their health and well-being, as well as for the continuation of their education. In many countries, few young people are equipped with the information, skills and resources needed to deal with a healthy transition to adulthood. Adequate programs, including media campaigns, and quality sex education for both in-school and out-of-school youth, would provide important information that would likely enhance young people's ability to correctly assess their risk of HIV infection and increase their use of condoms.

\section{REFERENCES}

1. Barreto A, Impacto Demografico do HIV/SIDA em MoçabiqueActualização, Maputo, Mozambique: Instituto Nacional de Estatistica (INE), Ministério da Saúde, Ministerio do Plano e Finanças, Centro de Estudos de População-UEM, Conselho Nacional de Combate ao HIV/SIDA, Faculdade de Medicina-UEM, Ministerio da Educação, 2002.

2. World Health Organization (WHO), Preventing HIV/AIDS in young people: a systematic review of the evidence from developing countries, WHO Technical Report Series, Geneva: WHO, 2006, No. 938

3. Gaspar MC et al., Mozambique Demographic and Health Survey, 1997, Calverton, MD, USA: INE and Macro International, 1998

4. Joint United Nations Programme on AIDS (UNAIDS), HIV Prevention Needs and Successes: A Tale of Three Countries. An Update on HIV Prevention Success in Senegal, Thailand and Uganda, Geneva: UNAIDS, 2001.

5. WHO, 2006, op. cit. (see reference 2).

6. Catania JA, Kegeles SM and Coates TJ, Towards an understanding of risk behavior: an AIDS risk reduction model (ARRM), Health Education Quarterly, 1990, 17(1):53-72.

7. Becker MH and Joseph JG, AIDS and behavioral change to reduce risk: a review, American Journal of Public Health, 1988, 78(4):394-410.

8. Magnani RJ et al., Reproductive health risk and protective factors among youth in Lusaka, Zambia, Journal of Adolescent Health, 2002, 30(1):76-86

9. Macintyre K, Brown L and Sosler S, "It's not what you know, but who you knew": examining the relationship between behavior change and AIDS mortality in Africa, AIDS Education Preview, 2001, 13(2):160-174.

10. Lindan $C$ et al., Knowledge, attitudes, and perceived risk of AIDS among urban Rwandan women: relationship to HIV infection and behavior change, AIDS, 1991, 5(8):993-1002.

11. Maswanya ES et al., Knowledge, risk perception of AIDS and reported sexual behaviour among students in secondary schools and colleges in Tanzania, Health Education Resources, 1999, 14(2):185-196. 
12. Sahlu T et al., Sexual behaviours, perception of risk of HIV infection, and factors associated with attending HIV post-test counseling in Ethiopia, AIDS, 1999, 13(10):1263-1272

13. Akwara PA, Madise NJ and Hinde A, Perception of risk of HIV/AIDS and sexual behaviour in Kenya, Journal of Biosocial Science, 2003, 35(3):385-411.

14. Macintyre K et al., Understanding perceptions of HIV risk among adolescents in KwaZulu-Natal, AIDS and Behavior, 2004, 8(3):237-250; and Prohaska TR et al., Determinants of self-perceived risk for AIDS, Journal of Health and Social Behavior, 1990, 31(4):384-394.

15. Caldwell JC, Orubuloye IO and Caldwell P, Obstacles to behavioural change to lessen the risk of HIV infection in the African AIDS epidemic: Nigerian research, in: Caldwell J et al., eds., Resistances to Behavioural Change to Reduce HIV/AIDS Infection in Predominantly Heterosexual Epidemics in Third World Countries, Canberra, Australia: Health Transition Centre, Australian National University, 1999, pp. 113-124

16. Maharaj P and Cleland J, Risk perception and condom use among married or cohabiting couples in KwaZulu-Natal, South Africa, International Family Planning Perspectives, 2005, 31(1):24-29.

17. Akande A, AIDS-related beliefs and behaviours of students: evidence from two countries (Zimbabwe and Nigeria), International Journal of Adolescence and Youth, 1994, 4(3-4):285-303.

18. Meekers D and Klein M, Determinants of condom use among young people in urban Cameroon, Studies in Family Planning, 2002, 33(4): 335-346.

19. Adih WK and Alexander CS, Determinants of condom use to prevent HIV infection among youth in Ghana, Journal of Adolescent Health, 1999, 24(1):63-72

20. INE, Inquerito Nacional Sobre Saúde Reproductiva e Comportamento Sexual dos Adolescents e Jovens, INJAD Relatório Final, Maputo, Mozambique: INE, 2003

21. Gaspar MC et al., 1998, op. cit. (see reference 3).

22. Leonard L et al., HIV prevention among male clients of female sex workers in Kaolack, Senegal: results of a peer education program, AIDS Education Preview, 2000, 12(1):21-37; and Meekers D, Going underground and going after women: trends in sexual risk behaviour among gold miners in South Africa, International Journal of STD E AIDS, 2000, 11(1):21-26.

23. Zellner SL, Condom use and the accuracy of AIDS knowledge in Côte d'Ivoire, International Family Planning Perspectives, 2003, 29(1):41-47

24. Ibid.; Kapiga SH et al., Predictors of AIDS knowledge, condom use and high-risk sexual behaviour among women in Dar-es-Salaam, Tanzania, International Journal of STD and AIDS, 1995, 6(3):175-183; and Agha S, Sexual activity and condom use in Lusaka, Zambia, International Family Planning Perspectives, 1998, 24(1):32-37.

25. Barreto A, 2002, op. cit. (see reference 1).

26. Sweat M et al., Cost-effectiveness of voluntary HIV-1 counseling and testing in reducing sexual transmission of HIV-1 in Kenya and Tanzania, Lancet, 2000, 356(9224):113-121.

27. Coovadia HM, Access to voluntary counseling and testing for HIV in developing countries, Annals of the New York Academic Sciences, 2000, Vol. 918 , pp. 57-63.

28. Gaspar MC et al., 1998, op. cit. (see reference 3).

29. Adetunji J, Condom use in marital and nonmarital relationships in Zimbabwe, International Family Planning Perspectives, 2000, 26(4):162200.

30. Varga CA, The condom conundrum: barriers to condom use among commercial sex workers in Durban, South Africa, African Journal of Reproductive Health, 1997, 1(1):74-88.

\section{RESUMEN}

Contexto: La relación entre la percepción que tiene las personas sobre su riesgo de contraer la infección del VIH y su uso del condón no es muy bien comprendida. Es crucial conocer esta relación para desarrollar estrategias eficaces para combatir la infección del VIH y el SIDA.

Métodos: Se utilizaron datos recopilados del Inquérito Nacional sobre Saúde Reprodutiva e Comportamento Sexual dos Jovens e Adolescentes, que se realizó en Mozambique en 2001, para comparar las evaluaciones de los propios jóvenes de 15-24 años de su riesgo de contraer la infección del VIH con las evaluaciones de los investigadores basadas en los datos de los jóvenes sobre su conducta sexual, actual y previa. Mediante análisis bivariados y de regresión, se examinó la relación entre la evaluación de riesgo correcta y la probabilidad del uso del condón durante la última relación sexual.

Resultados: El 27\% de las mujeres y el $80 \%$ de los hombres que se consideraron no encontrarse en situación de riesgo o de tener un riesgo reducido de contraer la infección del VIH, se encontraban realmente en un nivel de riesgo moderado o elevado. Tanto entre los hombres como entre las mujeres, la prevalencia del uso del condón durante la última relación sexual fue más del doble entre aquellos que indicaron su nivel riesgo correctamente que entre aquellos que no lo hicieron (30\% contra $14 \%$ para los hombres y $16 \%$ contra $6 \%$ para las mujeres). El análisis multivariado indicó que la evaluación correcta estuvo positivamente relacionada con el uso del condón; la asociación fue influenciada en gran medida por el uso del condón entre personas que nunca se habían casado. Los hombres que nunca se habian casado y que evaluaron su nivel de riesgo en forma correcta, eran un $18 \%$ más proclives que otros hombres a indicar que habían usado el condón; entre las mujeres que nunca se habían casado, las que tenían una percepción correcta eran un $17 \%$ más proclives que las otras mujeres a haber usado el condón.

Conclusiones: Los mensajes educativos en este campo deberán estar dirigidos para permitirles a las personas evaluar correctamente su propio nivel de riesgo de la infección del VIH, y deberán alentar un cambio de conducta basado en una autoevaluación con respecto al riesgo.

\section{RÉSUMÉ}

Contexte: Le rapport entre la perception individuelle du risque de contraction du VIH et l'usage du préservatif est mal compris. L'élaboration de stratégies utiles à la lutte contre le $\mathrm{VIH} /$ sida exige indispensablement que soit élucidé ce lien.

Méthodes: Les données de l'Adolescent and Young Adult Reproductive Health and Behavior Risk Survey menée en 2001 au Mozambique servent à comparer les évaluations données par les 15 à 24 ans de leur risque de contraction du VIH avec celles basées sur leur comportement sexuel passé et présent. L'analyse bivariée et de régression probit examine le rapport entre l'évaluation correcte du risque et la probabilité d'usage du préservatif aux derniers rapports sexuels.

Résultats: Vingt-sept pour cent des femmes et $80 \%$ des hommes qui estimaient courir un risque nul ou faible de contracter le VIH se trouvaient en fait dans les catégories de risque moyen ou élevé. Pour les hommes comme pour les femmes, la prévalence de l'usage du préservatif aux derniers rapports sexuels parmi ceux et celles qui avaient évalué correctement leur risque (30\% et 16\%, respectivement) a été le double de la prévalence 
chez les autres (14\% et 6\%). L'analyse multivariée révèle une association positive entre l'évaluation correcte et l'usage du préservatif. Ce lien était le résultat de l'usage du préservatif parmi les célibataires jamais encore marié(e)s: côté masculin et féminin, respectivement, les célibataires non encore marié(e)s qui avaient évalué correctement leur risque étaient 18\% et 17\% plus susceptibles que les autres d'en avoir déclaré l'usage.

Conclusions: Les messages de sensibilisation doivent aider l'individu à évaluer correctement son propre risque de contraction du VIH et encourager les changements comportementaux sur la base de l'auto-évaluation du risque.

\section{Acknowledgments}

The authors thank João Dias Loureiro and Manuel da Costa Gaspar for their invaluable support. They also acknowledge the following agencies for their financial support for the survey's implementation: United Nations Population Fund, U.S. Agency for International Development, UNICEF and the U.S. Centers for Disease Control and Prevention's Global AIDS Program.

Author contact: ndola@berkeley.edu 